Florida A\&M University College of Law

Scholarly Commons @ FAMU Law

$9-18-2020$

Raising the Impact Factor of the Library: Using the U.S. News \& World Report's Upcoming Academic Impact Law School Rankings to Boost the Academic Standing of Law Librarians

Paul J. McLaughlin

Follow this and additional works at: https://commons.law.famu.edu/library-facpub

Part of the Legal Education Commons, and the Legal Profession Commons 
This is an original manuscript / preprint of an article published by Taylor \& Francis in Legal Reference Services Quarterly on Sept. 18, 2020, available online: https://doi.org/10.1080/0270319X.2020.1818476.

Raising the Impact Factor of the Library: Using the U.S. News \& World Report's Upcoming Academic Impact Law School Rankings to Boost the Academic Standing of Law Librarians

Paul J. McLaughlin

Law Library, Florida Agricultural and Mechanical University, Orlando, Florida

Florida Agricultural and Mechanical University College of Law 201 Beggs Avenue Orlando Florida 32801 paul.mclaughlin@ famu.edu

Paul McLaughlin is an Instruction and Reference Librarian at the Florida Agricultural and Mechanical University's College of Law. 


\section{Raising the Impact Factor of the Library: Using the U.S. News \& World Report's Upcoming Academic Impact Law School Rankings to Boost the Academic Standing of Law Librarians}

This article recommends that law libraries and their librarians use the upcoming U.S. News \& World Report's academic rankings for law schools as an opportunity to enhance academic law libraries' standing in the legal profession and to elevate law librarians' statures within law schools.

Keywords: impact factors; law school rankings; law librarians

$\begin{array}{lr}\text { Introduction } & 2 \\ \text { Law School Rankings and Their Effects on Legal Education } & 4 \\ \text { Importance of Citations, Citation Analysis, and Impact Factors in the Law } & 6 \\ \text { Historical Importance of Legal Citations and the Rise of Citation Analysis } & 6 \\ \text { Citations' Relationship with Impact Factors } & 9 \\ \text { Impact Factors' Influence on Legal Publications and Scholarship } & 11 \\ \text { Use of Online Tools by Professors to Enhance Their Scholarship } & 11 \\ \text { Rise of Open-Access Journals } & 12 \\ \text { Establishment and Growth of Institutional Repositories } & 14 \\ \text { The Need for Law Libraries' and Librarians' Roles to Change and Grow } & 17 \\ \text { Law Libraries as Publication Hubs for Scholarship } & 18 \\ \text { Law Librarians as Networking Agents } & 19 \\ \text { Law Librarians as Scholars } & 20 \\ \text { Law Librarians as Tenured Faculty } & 22 \\ \text { Conclusion } & \end{array}$

\section{Introduction}

Academic reputation is an important commodity for law schools to cultivate due to its contribution to a school's perceived value to potential students and a 
school's ability to maintain tuition rates. ${ }^{1}$ Law schools expend large amounts of resources to attract quality faculty and students in order to improve their standings in published law school rankings. ${ }^{2}$ Law school rankings are meant to assist potential students in efficiently choosing where to send their applications. ${ }^{3}$ However, rankings of law schools often lack the necessary information to assist someone in making informed decisions, and they can imply that there are appreciable quality gaps between schools when there are actually none. ${ }^{4}$ Though law school rankings should be based on a variety of considerations, metrics involving academic impact are increasingly being used to measure the quality of individual scholars and law schools. ${ }^{5}$

The academic reputations of institutions and individual professors will soon have even more importance. U.S. News \& World Report's (U.S. News) Chief Data Strategist announced in May 2019 that the publication plans to create a scholarly impact ranking of law schools and may consider using it as part of U.S. News's overall law school rankings in the future. ${ }^{6}$ This article encourages librarians to use the upcoming

${ }^{1}$ See Brian Leiter, Measuring the Academic Distinction of Law Faculties, 29 J. Leg. Stud. 451, $451-52(2000)$.

${ }^{2} I d$. at $451-53$.

${ }^{3}$ See Richard A. Posner, Law School Rankings, 81 Ind. L.J. 13, 13-14 (2006).

${ }^{4} I d$.

${ }^{5}$ See Oren Perz et al., The Network of Law Reviews: Citation Cartels, Scientific Communities, and Journal Rankings, 82 Modern L. Rev. 240, 240-42 (2019).

${ }^{6}$ See Ltr. from Bob Morse, U.S. News \& World Report Chief Data Strategist, to Law School Dean Community, U.S. News Response to the Law School Community (May 2, 2019), 
U.S. News law school academic rankings as an opportunity to bolster their schools' reputations and emphasize the importance of the law library and its librarians to a law school's success. By promoting faculty publications through platforms such as online repositories and social media, supporting faculty research, and contributing their own research to their schools' pools of publications, librarians can meet their professional and ethical requirements and elevate the general standing of law librarians in legal education.

\section{Law School Rankings and Their Effects on Legal Education}

Law school rankings have been praised by some as helpful decisionmaking tools for potential law students and employers, and lambasted by others, for having too great an influence on legal education and providing faulty information to those who rely on them. ${ }^{7}$ Law school ranking systems consider expert opinions, incoming classes' LSAT scores and grade point averages, after-graduation employment rates, the funding levels of a school's library, and a variety of other measures. ${ }^{8}$ Due in part to the use of an academic- and practitioner-perceived reputation category, the schools in the top positions do not change ranks often, and if they do shift, they do not move far from their previous spots. ${ }^{9}$ The three major law school rankings are compiled

https://www.usnews.com/education/blogs/college-rankings-blog/articles/2019-05-02/usnews-responds-to-the-law-school-community.

${ }^{7}$ See William D. Hinderson \& Anderson P. Morriss, Student Quality as Measured by LSAT Scores: Migration Patterns in the U.S. News Rankings Era, 81 Ind. L.J. 163, 164-65 (2006). ${ }^{8} I d$. at $165-66$.

${ }^{9}$ See Richard Schmalbeck, The Durability of Law School Reputation, 48 J. Leg. Educ. 568, 570-73 (1998). 
by U.S. News, the Gourman Report, and the National Jurist. ${ }^{10}$ While the three often overlap in their top school rankings, the National Jurist's overall rankings shift more than the others due to the inclusion of such categories as quality of teaching and student-to-faculty ratios. ${ }^{11}$

Though many prospective students and employers look to law school rankings for information on which to base decisions, the criteria the rankings use have not been proven to reflect a law school's true performance. ${ }^{12}$ For example, it has been found that, within the U.S. News rankings, a small change in a school's score can have a major impact on its ranking. ${ }^{13}$ To improve their schools' rankings, some law schools have changed their practices in admissions, how they draft employment questionnaires, and student funding programs to boost statistics the various rankings measure. ${ }^{14}$ Law schools have also increased their efforts to attract second-year transfer students while admitting smaller incoming classes with higher LSAT scores and grade point averages to manipulate their standings. ${ }^{15}$

${ }^{10}$ See David C. Yamada, Same Old, Same Old: Law School Rankings and the Affirmation of Hierarchy, 31 Suffolk U. L. Rev. 249, 251 (1997).

${ }^{11} I d$. at $258-59$.

${ }^{12}$ See Jeffery E. Stake, The Interplay Between Law School Rankings, Reputation, and Resource Allocation: Ways Rankings Mislead, 81 IND. L.J. 229, 244-45 (2006).

${ }^{13}$ See Theodore P. Seto, Understanding the U.S. News Law Rankings, 60 St. Mary's L.J. 493, 507-9 (2007).

${ }^{14}$ See Darren Bush \& Jessica Peterson, Jukin' the Stats: The Gaming of Law School Rankings and How to Stop It, 45 Conn. L. Rev. 1235, 1251-58 (2012).

${ }^{15} I d$. 
A variety of complaints have been lodged regarding the categories used in law school rankings and the inclusion of incoming students' LSAT scores. The use of these measures has been argued to be in violation of the US Supreme Court's holding in Grutter v. Bollinger, ${ }^{16}$ which requires law schools to use "holistic" approaches to admitting students rather than use set benchmarks that would adversely impact minority applicants. ${ }^{17}$ Though many have argued against the publication of rankings because of their imprecision and detrimental impacts on law schools and their students, law school rankings have become an instrumental part of legal education. Indeed, law school administrators and incoming students must consider them when making decisions. ${ }^{18}$

\section{Importance of Citations, Citation Analysis, and Impact Factors in the Law}

\section{Historical Importance of Legal Citations and the Rise of Citation Analysis}

Citations are integral to the practice of law. Specifically, they provide the authentication of authority — for example, by pinpointing the sources of ideas in law journals, and by attributing data points for tracking legal concepts to empirical analysis experts. ${ }^{19}$

\footnotetext{
${ }^{16}$ Add case name? 539 U.S. 306, 309 (2003).
}

${ }^{17}$ See Alex M. Johnson, The Destruction of the Holistic Approach to Admissions: The Pernicious Effect of Ranking, 81 Ind. L.J. 309, 310-11 (2006).

${ }^{18}$ See Michael Sauder \& Wendy N. Espeland, Strength in Numbers? The Advantages of Multiple Rankings, 81 Ind. L.J. 205, 205-6 (2006).

${ }^{19}$ See Raizel Liebler \& June Liebert, Something Rotten in the State of Legal Citations: The Life Span of a United States Supreme Court Citation Containing an Internet Link (1996-2010), 15 Yale L.J. \& Tech. 273, 275-77 (2012). 
The study of legal citations began in England with legal practitioners and scholars who sought to organize and categorize the growing number of reported cases through citation schemes and corresponding indexes.20 Historically, practitioners in the United Kingdom who wanted to update the materials they were using, or find new sources to bolster their arguments, had to use a series of sources in a process called "noting up."'21 Until the 1940s, there had not been an attempt to create a centralized citation system for British law due to the large time span and number of sources the system would need to include.22 Even with efforts to simplify the process, updating materials in British law still requires using more than one noter-up publication.23 One of the earliest centralized legal citation analysis tools, created in 1873, was the Shepard's Citation Index, which allowed practitioners to find citations to cases in later opinions and other legal sources, and served as the model for current citation analysis for almost all areas of study. 24

The importance of citations in case opinions and academic journals has resulted in them being used in unintended ways. ${ }^{25}$ In the United States, legal citations have been

${ }^{20}$ See Fred R. Shapiro, Origins of Bibliometrics, Citation Indexing, and Citation Analysis: The Neglected Legal Literature, 43 J. Am. Soc'y Info. Sci. 337, 337-39 (1992).

${ }^{21}$ Stephen E. Young, Shepardizing English Law, 90 Law. Lib. J. 209, 209-10 (1998).

${ }^{22} I d$. at 210.

${ }^{23} I d$.

${ }^{24}$ See Fred R. Shapiro, The Most Cited Law Review Articles, 73 Calf. L. Rev. 1540, 1540-41 (1985).

${ }^{25}$ See Frederick Heckt et al., The Journal "Impact Factor": A Misnamed, Misleading, Misused Measure, 104 Cancer Genetics \& Cytogenetics 77, 80-81 (1998). 
studied since the 1950 s to uncover legal reasoning patterns and to measure the influence of an author, case holding, or judge in specific areas of law. ${ }^{26}$ A number of different factors impact how often a work is cited, including the impact factor of the publishing journal, the author's reputation, the country of publication, the source of funding, and the accessibility and visibility of the published work. ${ }^{27}$ Fred Shapiro has been credited with starting the practice of 'legal citology' with his 1985 piece, The Most Cited Law Review Articles, which examined the citation count of the most popular articles at the time, and who had been citing to each work. ${ }^{28}$

With the rise of digital information availability and computational power, citation analysis can now be used to evaluate and understand deep patterns in legal reasoning and scholarship. ${ }^{29}$ By studying citations as complex adaptive systems, relationships between case citations, regulatory actions' impacts, and legislative changes can be analyzed to create more efficient solutions for legal problems. ${ }^{30}$ Citation analysis is also used to create many kinds of bibliometrics, including the rate of obsolescence for publications, journal rankings, and author evaluations, which can be

${ }^{26}$ See Ryan Whalen, Legal Networks: The Promises and Challenges of Legal Network Analysis, 2016 Mich. St. L. Rev. 539, 548-51 (2016).

${ }^{27}$ See Iman Tahamtan et al., Factors Affecting Number of Citations: A Comprehensive Review of the Literature, 107 Scientometrics 1195, 1195-97 (2016).

${ }^{28}$ See J.M. Balkin \& Sanford Levinson, How to Win Cites and Influence People, 71 Chi.-Kent L. Rev. 843, 843 (1996).

${ }^{29}$ Whalen, supra note 26.

${ }^{30}$ See J. B. Ruhl et al., Harnessing Legal Complexity: Bringing Tools of Complexity Science to Bear on Improving Law, 355 Science 1377, 1377-78 (2017). 
used to analyze the influence of individual authors and institutions within a particular field. ${ }^{31}$ Article citation analysis has extended into monitoring social media posts through systems such as Plum Analytics, which tracks how many times an article is mentioned, and on which platforms an article is discussed. ${ }^{32}$

\section{Citations' Relationship with Impact Factors}

Impact ratings were created to provide a rough indication of the importance of an article or journal in a field. ${ }^{33}$ However, impact factors have a variety of inherent flaws and are often used as marketing gimmicks for journals and organizations rather than as a measure of an article's, author's, or journal's contribution to a field. ${ }^{34}$ Typical journal impact factors depend on the number of citations per year a journal receives when divided by the combined number of citations from the journal's previous two years' worth of citations. ${ }^{35}$ Citation counts for articles can be misleading or incomplete due to overlaps, mislabeling, and typographical errors, or due to citations not being in a form that allows the article to be recognized in another field. This, in turn, can distort an author's or journal's impact rating. ${ }^{36}$

${ }^{31}$ Shapiro, supra note 24, at 1541-42.

${ }^{32}$ See Ashley Sergiadis, Analysis of Tweets Mentioning Works from an Institutional Repository, 3 J. New Librarianship 129, 130-31 (2018).

${ }^{33}$ See Theodore Eisenberg, Assessing the SSRN-Based Law School Rankings, 81 Ind. L.J. 285, 285 (2006).

${ }^{34}$ Heckt et al., supra note 25 , at $78-81$.

${ }^{35}$ See Ludo Waltman, A Review of the Literature on Citation Impact Indicators, $10 \mathrm{~J}$. Informetrics 365, 380-81 (2016).

${ }^{36}$ See Mary Whisner, My Year of Citation Studies, Part 1, 110 Law Lib. J. 167, 170-75 (2018). 
Due to the isolated nature of legal scholarship and its unique citation system, legal articles are prone to linking errors and incomplete data when cited by journals outside the legal realm. ${ }^{37}$ Beyond quantitative measures of publications, qualitative considerations, such as the format of a publication or how a work has been cited (some articles get high citation counts because they are used as examples of poor practices), can influence an impact factor. ${ }^{38}$ Even when bibliometric analysis systems try to consider both qualitative and quantitative aspects of works with hybrid systems, inherent weaknesses in the new systems can have similar devaluation effects on a publication's rating. ${ }^{39}$

Impact factors for individual authors can be affected by their personal characteristics, the size of the school where they teach, and the reputations of the faculty member's degree-granting institutions. ${ }^{40}$ Impact factor systems often do not account for an author's works published in non-journal formats, such as books, which can lead to a

${ }^{37}$ See Benjamin J. Keele, Improving Digital Publishing of Legal Scholarship, 34 Leg. Ref. Servs. Q. 119, 131-32 (2015).

${ }^{38}$ See Nancy Levit, Scholarship Advice for New Law Professors in the Electronic Age, 16 Widener L.J. 947, 949-52 (2007).

${ }^{39}$ See Lawrence A. Cunningham, Scholarly Profit Margins: Reflections on the Web, 81 Ind. L.J. 271, 271-72 (2006).

${ }^{40}$ See generally Theodore Eisenberg \& Martin T. Wells, Ranking and Explaining the Scholarly Impact of Law Schools, 27 J. Leg. Stud. 373 (1998) (discussing the influences on impact factors for authors and institutions). 
scholar receiving less recognition. ${ }^{41}$ Impact factors also do not tend to consider such factors as an article's or author's specialized topical importance or publication time frames when quantifying an article's contribution to a subject. ${ }^{42}$

\section{Impact Factors' Influence on Legal Publications and Scholarship}

\section{Use of Online Tools by Professors to Enhance Their Scholarship}

To help meet the expectations of publishing influential articles and improving society through their scholarship, professors are using online tools to share their work with as broad an audience as possible. ${ }^{43}$ Scholars use online networking to find new information and make connections with experts who can help them expand their scholarly boundaries. ${ }^{44}$ The use of social media, social bookmarking, and collaborative pre-publishing sites, such as SSRN and arXiv, has caused current online research to be labeled "Research 2.0" due to its collaborative and user content-driven nature. ${ }^{45}$ Balkin and Sanford, in a tongue-in-cheek manner, have suggested professors use their

${ }^{41}$ See William M. Landes \& Richard A. Posner, Heavily Cited Articles in Law, 71 Chi.-Kent L. Rev. 825, 825-26 (1996).

${ }^{42}$ See Gregory Sisk et al., Scholarship Impact of Law School's Faculties in 2012: Applying Leiter Scores to Rank the Top Third, 9 U. St. Thomas L. J. 838, 846 (2012).

${ }^{43}$ See Carlos M. Ferreria \& Sandro Serpa, Online Visibility, Social Networks, and Glamorous Scientific Publications, 6 Int'1 J. Soc. Sci. Stud. 58, 58-59 (2018).

${ }^{44}$ See Paul Gevoni et al., Scholarly Communities, E-Research Literacy and the Academic Librarian, 24 Electronic Libr. 734, 737-42 (2006).

${ }^{45}$ See Tibor Koltay et al., The Shift of Information Literacy Towards Research 2.0, 41 J. Acad. Libr. 87, 89 (2015). 
academic connections and standing to boost their articles' visibility as much as possible. ${ }^{46}$ Whether following Balkin and Sanford's suggestion or not, many professors are actively contributing to blogs, Twitter feeds, and other online services, which they can use to leverage an increase in their publications' academic impact. ${ }^{47}$ If an article gets enough online attention, it can garner a higher impact rating in a shorter period of time than those which are not mentioned on the myriad of online platforms, much like a work of popular fiction hitting a must-read list or a music video going viral. ${ }^{48}$

\section{Rise of Open-Access Journals}

Few jurisdictions in the world allow broad access to legal information through governmental or other websites, which has been argued to be a violation of the human right to access the laws and related materials that can help citizens understand the rules that govern them. ${ }^{49}$ Open-access journals began as alternatives to expensive subscription journals and as a means to make scholarship freely available. ${ }^{50}$ The principles behind open access to legal information, including legal scholarship, were

${ }^{46}$ See J.M. Balkin \& Sanford Levinson, How to Win Cites and Influence People, 71 Chi.-Kent L. Rev. 843, 859 (1996).

${ }^{47}$ See Benjamin J. Keele, Improving Digital Publishing of Legal Scholarship, 34 Leg. Ref. Servs. Q. 119, 134-35 (2015).

${ }^{48}$ See Balkin \& Levinson, supra note 46 , at 847-50.

${ }^{49}$ See Richard A. Danner, Open Access to Legal Scholarship: Dropping the Barriers to Discourse and Dialogue, 7 J. Int'1 Com. L. \& Tech. 65, 66-68 (2012).

${ }^{50}$ See Albert N. Greco, Academic Libraries and the Economics of Scholarly Publishing in the Twenty-First Century: Portfolio Theory, Product Differentiation, Economic Rent, Perfect Price Discrimination, and the Cost of Prestige, 47 J. Scholarly Pub. 1, 17-20 (2015). 
articulated in the 2002 Montreal Declaration and the Declaration on Free Access to Law. ${ }^{51}$ The fundamental ideas behind open-access legal information have also been argued to be part of the Universal Declaration of Human Rights, the International Covenant on Economic, Social and Cultural Rights, and the International Convention on Civil and Political Rights. ${ }^{52}$ However, due to the entrenched positions of long-running journals and their publishers, which leverage their institutional prestige to maintain their market shares, open-access publishing has not become a full substitute for traditional publications. ${ }^{53}$

While some authors and journal editors have raised concerns about the increase in the online publication of legal scholarship, which diminishes journals' reputations and dilutes legal scholarship, a survey by Danner et al. found that the majority of authors are willing to have their work published in an online format so long as a print version is also made available. ${ }^{54}$ The increasing pressures on professors to publish have made publishing in open-access journals more popular, since articles appearing in those

${ }^{51}$ Richard A. Danner, Applying the Access Principle in Law: The Responsibilities of the Legal Scholar, 35 Int'1 J. Leg. Info. 355, 362-66 (2007).

${ }^{52} I d$.

${ }^{53}$ Greco, supra note 50, at 23-30.

${ }^{54}$ See Richard A. Danner et al., Print or Perish? Author's Attitudes Toward Electronic-Only Publication of Law Journals 8-14 (Conference paper presented at The Future of Law Libraries? The Future is Now, Harvard School of Law 2011), http://scholarship.law.duke.edu/faculty_scholarship/2393/. 
journals often see a 50 percent rise in short-term and long-term citation counts. ${ }^{55}$ Beyond helping boost the number of citations, open access provides interested individuals with opportunities to access legal information, encourages interdisciplinary scholarship, and promotes the international exchange of ideas. ${ }^{56}$ Publishing in openaccess journals also helps reduce the number of predatory journals by allowing authors a legitimate alternative to using questionable journals to get their scholarship published. ${ }^{57}$

\section{Establishment and Growth of Institutional Repositories}

The wider use of institutional repositories in law schools began in response to the Durham Statement on Open Access to Legal Scholarship, which encouraged law schools to make their journals and faculty scholarship freely accessible in digital formats. ${ }^{58}$ Beyond acting as gateways for a variety of sources of legal information, institutional repositories have become dissemination points for working papers, grey literature, and organizational information. ${ }^{59}$ Institutional repositories allow law schools

${ }^{55}$ See James M. Donovan et al., The Open Access Advantage for American Law Reviews, $97 \mathrm{~J}$. Pat. \& Trademark Off. Soc'y 4, 10-12 (2015).

${ }^{56}$ See Michael W. Carroll, The Movement for Open Access Law, 10 Lewis \& Clark L. Rev. 741, $755-57$ (2006).

${ }^{57}$ See David Moher et al., Stop This Waste of People, Animals, and Money, 549 Nat. News 23, 24-25 (2017).

${ }^{58}$ See Yolanda P. Jones, Libraries Can Help: Institutional Repositories, 30 Thomas. M. Cooley L. Rev. 254, 254-55 (2013).

${ }^{59}$ See Daniel G. Dorner \& James Revell, Subject Librarians' Perceptions of Institutional Repositories as an Information Resource, 36 Online Info. Rev. 261, 264 (2012). 
to create collections tailored to their unique cultures, faculty needs, preservable item types, and technological capabilities. ${ }^{60}$ The law school community has created one of the highest concentrations of institutional repositories in academia and has consistently increased its repository holdings at a greater rate than those of other disciplines. ${ }^{61}$

\section{The Need for Law Libraries' and Librarians' Roles to Change and Grow}

Law librarians are the central access points to a variety of legal information sources in electronic and print formats, including academic scholarship, commercial publications, government documents, and multidisciplinary sources. ${ }^{62}$ Law librarians also contribute to the creation of legal scholarship by supporting faculty research and assisting students in preparing and publishing law journals. ${ }^{63}$ Danner has written that law librarians can be considered members of one of the "gold-collar" professions, and that their specialized knowledge and technical skills allow them to be effective in a variety of positions and support roles. ${ }^{64}$ While law librarians have a

${ }^{60}$ See Nancy Y. McGovern \& April C. McKay, Leveraging Short-Term Opportunities to Address Long-Term Obligations: A Perspective on Institutional Repositories and Digital Preservation Programs, 57 Lib. Trends 262, 270-74 (2008).

${ }^{61}$ See Ellen Dubinsky, A Current Snapshot of Institutional Repositories: Growth Rates, Disciplinary Content, and Faculty Contributions, 2 J. Lib. \& Scholarly Comm. 1, 9-11 (2014).

${ }^{62}$ Levit, supra note 38, at 967-70.

${ }^{63}$ See Benjamin J. Keele \& Michelle Pearse, How Librarians Can Help Improve Law Journal Publishing, 104 Law Lib. J. 383, 383-84 (2018).

${ }^{64}$ Richard A Danner, From the Editor: Gold-Collar Librarians, 78 L. Lib. J. 213, 214-16 (1986). 
special status in America's legal system, their importance is being called into question. ${ }^{65}$ Law libraries and their librarians face a number of changes due to smaller library budgets, the shift from physical to electronic resources, the increase in costs for journal access, and public commentators questioning the value of a library to society. ${ }^{66}$ As libraries have shifted towards more electronic resources and different ways of communicating with patrons, librarians' roles have blurred to the extent that some commentators view them as technology specialists who may not warrant a special classification apart from others who work in the information field. ${ }^{67}$ Some experts believe law libraries will cease to be a part of legal education, and that law schools will repurpose the resources and space devoted to them. ${ }^{68}$ Other experts, such as Hirsh, acknowledge libraries will become obsolete if they continue as they are, but contend

${ }^{65}$ See generally Jootaek Lee, Frontiers of Legal Information: The U.S. Law Libraries of the Future, 43 Int'l J. Leg. Info. 411 (2015) (describing the historical significance of law librarians to the practice of law and how their roles will have to change to meet current educational and practice needs).

${ }^{66}$ See generally Ursula Gorham \& Paul T. Jaeger, The Law School Library or the Library at the Law School? How Lessons from Other Types of Libraries Can Inform the Evolution of the Academic Law Library in the Digital Age, 109 Law. Lib. J. 51 (2017) (discussing the ways law libraries can use strategies from other kinds of libraries to remain relevant to their patrons and schools).

${ }^{67}$ See Richard A. Danner, Redefining a Profession, 90 L. Libr. J. 315, 318-325 (1998).

${ }^{68}$ See Kenneth J. Hirsh, Like Mark Twain: The Death of Academic Law Libraries Is an Exaggeration, 106 Law Lib. J. 521, 521-23 (2014). 
that if librarians are creative with their resources and skills, they can keep their libraries functioning as vital parts of their law schools. ${ }^{69}$

\section{Law Libraries as Publication Hubs for Scholarship}

Libraries have been heralded as organizations that support public access to information in all formats and without undue influence from outside organizations; that constantly adapt to meet patron needs; and that ensure the integrity of the information they include in their collections. ${ }^{70}$ Using their positions in academia and their law schools, law librarians can be key in publicizing faculty work and augmenting the status of their law schools. ${ }^{71}$ With the rise of open-access journals, academic libraries are becoming centers of publication for scholarly works. ${ }^{72}$ Danner and Bintliff have written that scholarly commons efforts by libraries help academia's "gift economy," which focuses on sharing information and corroboration. ${ }^{73}$ Law librarians can help their schools' faculty publications and student journals be more visible by creating and maintaining institutional repositories, which can serve as public archives and publishing

${ }^{69} \mathrm{Id}$. at $526-29$.

${ }^{70}$ See Richard A. Danner, Skating with Donovan: Thoughts on Librarianship as a Profession, 27 Leg. Ref. Servs. Q. 117, 119-24 (2008).

${ }^{71}$ See Simon Canick, Library Services for the Self-Interested Law School: Enhancing the Visibility of Faculty Scholarship, 105 Law Lib. J. 175, 186-88 (2013).

${ }^{72}$ See Clifford Lynch, Updating the Agenda for Academic Libraries and Scholarly Communications, 78 COLLEGE \& RESEARCH LiBS. 126, 128 (2017).

${ }^{73}$ Richard A. Danner \& Barbara Bintliff, Academic Freedom Issues for Academic Libraries, 25 Leg. Ref. Servs. Q. 13, 26-27 (2006). 
platforms for their schools' scholarly output. ${ }^{74}$ By participating in open-access publishing and creating resource-sharing networks with other libraries, librarians allow a wider audience to access their schools' scholarship, thereby reducing the need to maintain costly journal subscriptions. ${ }^{75}$ By taking on active roles in the creation and dispersal of electronic information, librarians can also help ensure citation practices are followed, and that the proper metadata is provided so items are discoverable online. ${ }^{76}$

\section{Law Librarians as Networking Agents}

Librarians have been called upon to become active in providing electronic research services and to bolster communication between scholars using online platforms, such as YouTube, and professional networking sites like LinkedIn. ${ }^{77}$ Librarians can serve as communication agents for their schools' faculty, and purveyors of their schools' scholarship, through the use of online platforms and online scholarly discussion groups. ${ }^{78}$ Using tools such as social media, law librarians can monitor scholarship trends and add to academic discussions by providing information about

${ }^{74}$ See Yolanda P. Jones, Libraries Can Help: Institutional Repositories, 30 Thomas. M. Cooley L. Rev. 253, 254-55 (2013).

${ }^{75}$ See James M. Donovan \& Carol A. Watson, Citation Advantage of Open Access Legal Scholarship, 103 Law. Lib. J. 533, 554-56 (2011).

${ }^{76}$ Koltay, supra note 44 , at $97-101$.

${ }^{77}$ See Jayshree Mamtora, Transforming Library Research Services: Towards a Collaborative Partnership, 34 Lib. Mgt. 353, 359-65 (2013).

${ }^{78}$ See Paul Genoni et al., Scholarly Communications, E-Research Literacy and the Academic Librarian, 24 Elec. Lib. 734, 743-44 (2006). 
relevant faculty publications. ${ }^{79}$

While they can provide opportunities to make connections with scholars, the use of social media and other online communication tools comes with a variety of ethical pitfalls of which librarians must be aware ${ }^{80}$ Librarians must balance the need to maintain the privacy of information seekers, while reaching out to individuals or online groups, to gather information and maintain the anonymity of those who share materials and do not wish to be identified. ${ }^{81}$ Librarians should also take extra care when conducting online outreach activities with assistance from, or in coordination with, law students due to the possibility of a state bar investigating a student's online activities. ${ }^{82}$

\section{Law Librarians as Scholars}

Law librarians have a professional responsibility to publish scholarship in order to fulfill their public service obligations and to enhance the profession of librarianship. ${ }^{83}$ Beyond supporting their schools by providing instructional and research support for

${ }^{79}$ See generally James Mullan, Should We Be More Social? Law Librarians and Social Media, 9 Leg. Info. Mgt. 175 (2009) (discussing the various ways law librarians can use online tools and social media to connect with others).

${ }^{80}$ See Sarah Shik Lamdan, Social Media Privacy: A Rallying Cry to Librarians, 85 Lib. Q. 261, 271-74 (2015).

${ }^{81} I d$.

${ }^{82}$ See Jessica Belle, Social Media Policies for Character and Fitness Evaluations, 8 Wash. J. L. Tech. \& Arts 107, 110-14 (2012).

${ }^{83}$ See Donald J. Dunn, The Law Librarian's Obligation to Publish, 75 Law Lib. J. 225, 230-31 (1982). 
faculty, librarians can contribute to a law school's body of scholarship. ${ }^{84}$ However, depending on how a school defines the status of their librarians, a librarian's scholarship may not be included in impact studies or rankings. ${ }^{85}$ Members of a school's teaching staff, such as clinical professors, librarians, and writing professors, may have their work counted as part of a school's scholarship but are not included as part of the school's faculty count. ${ }^{86}$ Other studies and rankings choose to exclude clinical instructors' and librarians' publications due to their positions lacking a requirement to produce scholarship. ${ }^{87}$ For example, the Leiter Rankings do not incorporate non-faculty publications, which excludes the published works of clinical instructors, librarians, and writing professors, or those who are not eligible for tenured faculty status at their schools. $^{88}$

\section{Law Librarians as Tenured Faculty}

Librarians' rankings in academia have many variations based on their

${ }^{84}$ See Carol A. Parker, How Law Schools Benefit When Librarians Publish, Teach, and Hold Faculty Status, 30 Leg. Ref. Servs. Q. 237, 238-39 (2011).

${ }^{85}$ See Tracy E. George, An Empirical Study of Empirical Legal Scholarship, 81 Ind. L.J. 141, $151-52(2006)$.

${ }^{86}$ See Colleen M. Cullen \& Randall Kalberg, Chicago-Kent Law Review Faculty Scholarship Survey, 70 Chi.-Kent L. Rev. 1445, 1450 (1995).

${ }^{87}$ See Theodore Eisenberg \& Martine T. Wells, Ranking and Explaining the Scholarly Impact of Law Schools, 27 J. Leg. Stud. 373, 379 (1998).

${ }^{88}$ See Gary M. Lucas, Measuring Scholarly Impact: A Guide for Law School Administrators and Legal Scholars, 165 U. Pa. L. Rev. Online 165, 170 (2016). 
institutions' practices. $^{89}$ The majority of law librarian positions have required applicants to have a master's degree in library science and a juris doctor, which would allow librarians to be faculty based on educational merit. ${ }^{90}$ As budget cuts continue, and pressures to create quality scholarship increase, law librarians who are non-tenured faculty, and whose scholarship is not counted as contributing to a school's academic prestige, are in danger of being considered non-vital and expendable. ${ }^{91}$

Law librarians can help maintain their libraries' budgets, and have a greater chance to retain their positions, if they can help bolster their schools' academic standing, which would require them to become full members of a school's faculty. ${ }^{92}$ Despite some individuals and organizations calling for librarians to have established performance standards and the means to become tenured faculty, law librarians have not made a push to become full faculty members - due in part to such status not greatly impacting them or their law schools. ${ }^{93}$ The need for librarians to have faculty and tenure status has become critical for law library directors, who have seen their prestige in law

${ }^{89}$ See Nathan Hosburgh, Librarian Faculty Status: What Does It Mean in Academia?, 1 Lib. Phil. \& Prac. 30, 32-34 (2011).

${ }^{90}$ See Elizabeth Caulfield, Is This a Profession? Establishing Educational Criteria for Law Librarians, 106 L. Lib. J. 287, 299-300 (2014).

${ }^{91}$ See James G. Milles, Legal Education in Crisis, and Why Law Libraries Are Doomed, 106 L. Lib. J. 507, 516-20 (2014).

${ }^{92} I d$. at 520.

${ }^{93}$ See Carol A. Parker, The Need for Faculty Status and Uniform Tenure Requirements for Law Librarians, 103 L. Lib. J. 7, 8 (2001). 
schools decline. ${ }^{94}$ Despite ABA requirements for law library directors to have faculty status, directors are seeing their tenure opportunities and faculty status disappear as law schools devalue their libraries. ${ }^{95}$ For librarians and library directors to have tenured status, and be on par with faculty, they must engage in faculty governance, publish, and teach. ${ }^{96}$ Whether a librarian has the opportunity to earn tenure or faculty status often depends on the librarian conducting research and publishing. ${ }^{97}$ While librarians are known to produce scholarship on library administration issues, librarians would need to branch out in terms of their topical coverage in order to conform to the general publication requirements for tenure. ${ }^{98}$

\section{Conclusion}

While law school rankings have been criticized for having a number of flaws, they are a popular and easy-to-use way to find information on the nation's law schools. The upcoming creation of the U.S. News academic rankings for law schools will add more layers of complexity to the already convoluted law school ranking system. The new academic ranking system will have to contend with the many weaknesses inherent in impact factors and citation counts in order to make meaningful determinations of an individual scholar's academic contributions. The next step will involve compiling the efforts of the law school's entire faculty in order to ascertain the

${ }^{94}$ See Michael J. Slinger \& Sarah C. Slinger, The Career Path, Education, and Activities of Law Library Directors Revisited Twenty-Five Years Later, 107 L. Lib. J. 175, 193-94 (2015).

${ }^{95}$ Milles, supra note 91, at 519-20.

${ }^{96}$ Parker, supra note 93 , at 16-17.

${ }^{97}$ Hosburgh, supra note 89.

${ }^{98}$ Parker, supra note 93, at 25-29. 
school's standing. The impact of the new ranking system on legal education and scholarship could cause shifts in law schools' hiring and evaluation standards for their faculty as they try to meet the new criteria of the academic ranking system and increase the use of open-access journals in an effort to boost citations to faculty works.

The creation of the U.S. News academic rankings could be a threat or a boon to academic law libraries. As law schools face more pressure to generate publications that are counted in impact factors, non-publishing positions may be reassessed and eliminated to provide funding for those who can raise a school's standing with their scholarship. With the majority of law librarians not being counted as faculty members, and not producing scholarship, a logical place for law schools to look to eliminate positions and redirect funding would be their law libraries. With the new pressures for law schools to create scholarship, taken in combination with the declining views of the importance of law libraries and law library directors, law libraries and their librarians could face a struggle to continue to be a central part of legal education.

Librarians may be able to not only boost their law schools' scholarship but also raise their status in legal education if they use their full array of skills and leverage the opportunities the U.S. News academic rankings will afford them. Law libraries have already begun the process of becoming central to the publication of scholarship through the establishment of institutional repositories. By becoming more involved in the dissemination of their law schools' faculty research through open-access projects hosted on their repositories, librarians can be key to their law schools' scholarship publication efforts. Law librarians can use their knowledge to help ensure publications held in their schools' repositories adhere to proper citation conventions and create appropriate metadata so publications can be found through online database searches. Law librarians 
can also use their research networking skills through online communications platforms to help their faculty connect with experts in their areas of scholarship and announce the publication of faculty members' work to those who might be interested.

To take full advantage of the forthcoming U.S. News academic rankings, librarians will need to produce scholarship of their own to help their law schools' scholastic rankings and to emphasize the qualifications and variety of skills they possess. For librarian publications to have their full impact, law librarians must be included as full faculty members with publication requirements and the possibility of obtaining tenure. While having faculty member governance duties and publication requirements would add more demands for librarians' time, librarians would benefit from being included in their law schools' faculty meetings and gaining the relative protection of being publishing members of a school's staff.

The introduction of the U.S. News academic law school rankings will trigger changes in legal education and how law schools operate. Law librarians can help their schools face the ensuing challenges and reestablish the law library as a central part of the law school in the minds of law school administrators and legal professionals. If law librarians use their skills to their utmost, they can demonstrate the value of law librarians to their schools and society, reinforce their status as professionals deserving proper recognition for their education and efforts, and meet their professional obligations to publish scholarship that helps members of society with their legal information needs. 